\title{
Redefining Mother: A Legal Matrix for New Reproductive Technologies
}

\author{
Andrea E. Stumpf
}

\section{INTRODUCTION}

The legal definition of "mother" has traditionally carried an unshakeable presumption: She was the one from whose womb the child came. ${ }^{1}$ While the mother's incumbent rights and obligations were not always as easy to define, at least her identity was ${ }^{2}$ - until recently. New reproductive technologies, such as artificial insemination, in vitro fertilization, embryo transfers, and surrogate motherhood, have shaken the unshakeable. ${ }^{3}$ Unguided by new legislation and inclined to preserve their timeworn test of mother, courts are creating a convoluted branch of law. ${ }^{4}$

This Note proposes a comprehensive legal matrix to accommodate shift-

1. This presumption is not articulated as such in the legal field, for the presumption has been so absolute as to have generated no controversy. In this Note, "presumption of biology" describes the unacknowledged but pervasive rule for determining the placement of maternal rights and obligations. A recent surrogate mother case has newly raised the issue. Said the judge: "We really have no definition of 'mother' in our lawbooks . . . . 'Mother' was believed to have been so basic that no definition was deemed necessary." Surrogate Has Baby Conceived in Laboratory, N.Y. Times, Apr. 17, 1986, at A26, col. 4.

2. The mother's identity was clear as long as the birth itself was observed. The English tradition of hereditary succession placed importance on the witnessing of births, as was made clear in the politicized case of James Francis Edward, Prince of Wales, in 1688. Accusations that a child had been smuggled in with a warming pan led to French exile for the "Old Pretender" and were used to justify the invasion of England by William of Orange. See Kenyon, The Birth of the Old Pretender, 1963 Hist. TODAy 418. Similarly, current Jewish tenets reflect the certainty of maternity by preserving the tradition that a child born of a Jewish mother retains Jewish status regardless of the father's ethnicity, whereas a child born of the reverse combination does not. See B. BETTELHEIM, THE CHLDREN Of THe Dream 44 (1969); M. Mielziner, The Jewish LaW of Marriage and Divorce In ANCIENT AND Modern Times 97 (1901). During colonial rule, the regulation of slaves created a society of matrilineal descent. The absolutist nature of North American colonial racism and the biological basis of color led directly to a system where children of slave mothers were designated slaves. F. Tannenbaum, Slave and Citizen: The Negro in the Americas 49 (1946).

3. These new technologies open significant new possibilities for infertile parents. In the past, inability to procreate had to be accepted as regrettable but unalterable. For example historically, impotence-inability to copulate-deserved a marriage annulment under Canon Law, 1983 CoDE c.1068, § 1, but sterility-inability to procreate-did not, 1983 CoDE c.1068, § 3. See 1 O. Cloran, Previews and Practical. Cases on Marriage 193 (1960).

4. For discussions of the gap between law and reproductive technologies, see, for example, Black, Legal Problems of Surrogate Motherhood, 16 NEw ENG. L. REv. 373 (1981); Mawdsley, Surrogate Parenthood: A Need for Legislative Direction, 71 ILL. B.J. 412 (1983); Note, Surrogate Mothers: The Legal Issues, 7 AM. J.L. \& MEd. 323 (1981); Comment, Contracts To Bear a Child, 66 CaLIF. L. Rev. 611 (1978); Comment, Parenthood by Proxy: Legal Implications of Surrogate Birth, 67 Iowa L. REv. 385 (1982); Comment, Surrogate Motherhood in California: Legislative Proposals, 18 San Diego L. Rev. 341 (1981); Comment, Surrogate Mother Agreements: Contemporary Legal Aspects of a Biblical Notion, 16 U. RICH. L. REv. 467 (1982). 
ing parental rights and obligations in this rapidly changing area of family law. By dividing the procreative process into stages, the matrix places new emphasis on the psychological dimensions of procreating parents and affords new flexibility in the allocation of rights and obligations between procreating parties. Although the matrix is useful for generating legal conclusions for all reproductive technologies, this Note focuses on surrogate motherhood. ${ }^{5}$

After analyzing deficiencies of judicial and legislative treatment of surrogate motherhood, the Note discusses each of four stages of procreation for surrogate motherhood. Presentation of the stages will emphasize respectively the rights of initiating parents, the involvement of third party professionals, the rights of the surrogate mother, and the interests of the child.

\section{The Legal Gontext of Surrogate Motherhood}

\section{A. Arduous Process and Inadequate Outcomes}

Surrogate motherhood does not appropriately fit into any existing legal scheme. No statute specifically addressing surrogate motherhood has been enacted, ${ }^{8}$ nor has the historical development of family law contemplated surrogate motherhood. Courts have considered surrogate motherhood only a handful of times, and there are only a few state attorney general opinions on the topic. ${ }^{7}$ Without exception, legal treatment has been fundamentally inadequate. The realities of surrogate arrangements are being obscured, and the ends of these arrangements are being obstructed. ${ }^{8}$

5. In a surrogate arrangement, a surrogate mother offers to be artificially inseminated, carry the child to term, and then give the child to the biological father. Typically, a lawyer draws up a contract for the parties that includes compensation for the surrogate mother. This Note assumes the basic case. The surrogate arrangement is initiated on behalf of an infertile wife, who will have no genetic link to the child, and her husband, who contributes sperm. The surrogate mother contributes both egg and womb. This assumption does not preclude the possibility that such an arrangement can be initiated by an unmarried couple or by an individual, or that the wife of the natural father may be sufficiently fertile to provide the egg. Arguments in this Note can be extended to such situations as well, but their development is beyond the scope of this Note.

6. Twelve proposed surrogate mother statutes are reprinted in 1982-85 Human Reproduction \& L. Rep. (Legal-Medical Studies) R71-109 (1984) [hereinafter Reproductive Law Rep.]. The range of prescriptions and proscriptions in these proposed bills indicates the uncertainty with which state legislatures are addressing surrogate motherhood. E.g., compare R.I. H. 6132, Reproductive Law Rep. at R99 (treats surrogate arrangement as business venture) with N.J. Ass. 3139, Reproductive Law Rep. at R93 (unlawful to assist materially as intermediary) and N.Y. H. 6624, Reproductive Law Rep. at R97-98 (attorney representation allowed but surrogate mother may not receive fee for service).

7. See Op. Kan. Att'y Gen. No. 82-150 (July 2, 1982) (LEXIS, States library, KanAg file); Op. Ky. Att'y Gen. No. 81-18 (Jan. 26, 1981) (photo. reprint on file with author); Op. La. Att'y Gen. No. 83-869 (Oct. 18, 1983) (LEXIS, States library, LaAg file); Op. Ohio Att'y Gen No. 83-001 (Jan. 3, 1983) (LEXIS, States library, OhAg file).

8. The United Kingdom has recently enacted legislation constituting obstruction. See Surrogacy Arrangements Act 1985, §§ 1-3 (LEXIS, Enggen library, Statis file). Following recommendations from the Warnock Committee, the regulations criminalize all but informal, private, uncompensated 
In re Baby $\mathrm{Girl}^{\ominus}$ exemplifies the exigencies created by current application of family law. A husband and wife, unable but desiring to have a child, sought assistance from another woman willing to act as a surrogate mother. As contractually agreed, the surrogate mother conceived a child with the sperm of the infertile wife's husband and, upon birth, relinquished that child to the natural father and his wife. Although the child immediately joined the initially desiring parents, legal presumption continued to place the maternal rights in the surrogate mother as the biological mother. The presumption of legitimacy ${ }^{10}$ placed the paternal rights in the husband of the surrogate mother, although at the time of contracting, he had no direct interest in the arrangement or the child. Consequently, the presumed parents had to seek judicial remedy to reflect the transfer of the child that had already taken place. Without tailor-made legal mechanisms, the surrogate mother and her husband sought recourse through the state Termination Act ${ }^{11}$ to terminate their parental rights voluntarily.

Resort to judicial assistance failed to correct the distortions caused by the legal presumptions. Referring to state adoption statutes, the court refused to terminate the parental rights because the parties had not sought permission from an authorized adoption agency to transfer the child. The

arrangements. See Dep't of Health \& Social SeC., RePort of the Comm. of Inquiry into HuMAN FERTILISATION AND EMBRYOLOGY 42-47 (London 1984). Because the use of brokers and advertisements is prohibited, surrogate arrangements in the United Kingdom can only result from fortuitous and improbable connections. The only permissible arrangements are precisely those that are least safeguarded. See infra note 57. Australia has passed similar legislation. See Singer, Making Laws on Making Babies, 15 Hastings Center Rep. 5-6 (1985).

9. 9 Fam. L. Rep. (BNA) 2348 (Ky. Cir. Ct. 1983) (digest of opinion).

10. The relevant form of the presumption of legitimacy places paternity of a child born during wedlock in the mother's husband. Pater est quem nuptiae demonstrant. J. LONG, A TREATISE ON THE LAW of Domestic Relations $§ 252$ (1923); see also W. Wanenmacher, Canonical Evidence in Marriage Cases 244 (1935) (Canon Law 1917 Code c.1115, §§ 1, 2).

The presumption of legitimacy frequently has been described as the strongest presumption known to law. In some jurisdictions it carried a standard of proof that rendered rebuttal practically impossible. See Hanley v. Flanigan, 104 Misc. 2d 698, 700, 428 N.Y.S.2d 865, 867 (1980) (presumption of legitimacy " "will not fail unless common sense and reason are outraged . . . ." (quoting In re Findlay, 253 N.Y. 1, 8, 170 N.E. 471, 473 (1930))). Rather than a preponderance of evidence, overcoming this presumption traditionally required an indisputable case. Some courts established a standard of impossibility to overturn the presumption. See, e.g., Ewell v. Ewell, 163 N.C. 233, 79 S.E. 509 (1913) (irrebuttable if husband was "within the four seas" for necessary length of time). The A.L.I. Model Code of Evidence developed a separate rule for the presumption of legitimacy, burdening it with a uniquely strict measure of persuasion. MODEL CODE of EvidENCE Rule 703 (1942); see Morgan, Further Observations on Presumptions, 16 S. CAL. L. REV. 245 (1943). However, the presumption of legitimacy-despite various public policy justifications of safeguarding against humiliation and preserving family peace and harmony-is no longer the practical absolute it once was. See $1 \mathrm{~S}$. Schatkin, Disputed Paternity Proceedings $\$ 1.02$ (4th rev. ed. 1985). Increasing use of artificial insemination and increasing sophistication of paternity determinations have contributed to its decline. See, e.g., Cherchez la gene, The Economist, Jan. 4, 1986, at 66-67 (completely reliable new genetic test for paternity and maternity).

11. Ky. Rev. Stat. ANN. $\$ 199.601$ (Baldwin 1985) (providing for voluntary termination of parental rights by petition filed by parent, followed by court inquiry and decision). 
court reasoned that the Termination Act should not serve as a paternity act by giving the biological father exclusive rights to the child.

Baby Girl shows that although the surrogate mother physically relinquishes the child to the initiating parents, the transfer is not complete until the legal rights to the child are completely vested in the natural father and his wife. ${ }^{12}$ Currently every state requires some legal action to legitimate fully the relationship between the initiating parents and the child. ${ }^{13}$ These actions include proceedings to terminate parental rights of the surrogate family, to order filiation of the natural father, and to grant adoption rights to the infertile wife. ${ }^{14}$

\section{B. Sources of Legal Ineptitude}

The need for these proceedings is due partly to the use of legal presumptions with little or no opportunity for rebuttal. Two significant presumptions infringe on surrogate motherhood: the presumption of biology ${ }^{15}$ and the presumption of legitimacy. ${ }^{16}$ Both presumptions are tools by which law has perpetuated the nuclear family-father-mother-child-to the exclusion of alternate combinations of parental relations. ${ }^{17}$ These

12. This transfer of rights is most critical for the infertile wife. Under current law, the infertile wife is treated as though she were devoid of any relationship to the child. She must gain rights to the child through adoption, and otherwise has no legal standing to obtain a custody decree. Such legal isolation from the child is inappropriate. The fact that the infertile wife has no genetic or gestational link to the child does not mean that she had no procreative role in its birth or that she has no procreative intent in assuming the child as her progeny. See infra notes 34-36 and accompanying text.

13. Some states have indicated that the necessary legal steps may not be based on surrogate contracts because these contracts are illegal or unenforceable. For example, the Kentucky Attorney General declared surrogate contracts illegal, although he endorsed two noncontractual remedies for surrogate motherhood disputes: 1) "If the surrogate mother decides to keep the child, the natural father ... has the right to seek custody of his child" and 2) "[i]f the natural father and his wife decide they do not want to have custody of or adopt the child, . . . . [the surrogate mother] could institute a paternity action." Op. Ky. Att'y Gen. No. 81-18 (Jan. 26, 1981). The state supreme court, holding the contract voidable but not void, allowed Surrogate Parenting Associates to continue facilitating surrogate contracts. Surrogate Parenting Assocs. v. Kentucky, 704 S.W.2d 209 (Ky. 1986).

14. A number of proposed statutes would explicitly cadify such proceedings for surrogate arrangements. See, e.g, Minn. H. 534, Reproductive Law Rep., supra note 6, at R89-92; S.C. H. 2098, Reproductive Law Rep., supra note 6, at R100-08. Both require an adoption petition by the wife of the natural father.

15. See supra note 1 .

16. See supra note 10. Surrogate cases in which the presumption of legitimacy appears include In re R.K.S., 10 Fam. L. Rep. (BNA) 1383 (D.C. Super. Ct. Fam. Div. 1984) (digest of opinion) (inconclusive documents must be supplemented by blood test for rebuttal); In re Baby Girl, 9 Fam. L. Rep. (BNA) 2348 (Ky. Cir. Ct. 1983) (affidavit of artificial insemination insufficient rebuttal without positive proof of no access by husband and blood grouping); Syrkowski v. Appleyard, 420 Mich. 367, 362 N.W.2d 211 (1985) (natural father's filing of notice of paternity creates rebuttable presumption of paternity).

17. Institutional preference has reinforced a minimal family ordering of married parents and their legitimate offspring, constituting a relational triad. See B. MAlinowski, SEX, CulTURE, AND MYrH 63 (1962) ("The most important moral and legal rule . . . is that no child should be brought into the world without a man-and one man at that-assuming the role of sociological father . . . ."); W. Goode, The Family 21 (1964) ("Malinowski's Principle should properly be extended to mother- 
well-established presumptions disregard fundamental aspects of surrogate arrangements and legally define the status of parties in a way that misallocates rights and obligations.

Judicial ineptitude in surrogate mother cases can also be traced to the selective and arbitrary use of statutes. ${ }^{18}$ Courts inconsistently apply statutes to surrogate cases, usually in ways that hinder surrogate arrangements. In most cases, courts have held the parties to be statutorily barred from proceeding.

Further problems arise from piecemeal adjudication of independent elements of the surrogate arrangement, with little or no regard for the arrangement as an entirety. ${ }^{19}$ Five activities in surrogate parenting have been prone to separate treatment by courts: 1) artificial insemination, 2) payment of fees to a biological mother, 3) agreement by a biological

hood as well . . . "); B. Berger \& P. Berger, The War Over The Family: Capturing the Middle Ground 187-93 (1983) (defending father-mother-child as validated by history). But $c f$. Moore v. City of East Cleveland, 431 U.S. 494, 504 (1977) ("Ours is by no means a tradition limited to respect for the bonds uniting the members of the nuclear family."); A. SkolNICK \& J. SkoLNICK, Family in Transition: Rethinking Marriage, Sexuality, Ghild Rearing, and Family OrGANIZATION 75-78 (1971) (family consists of three basic dyads, husband-wife, mother-child, fatherchild, which can be combined in alternate ways within community). See generally Collier, Rosaldo \& Yanagisako, Is There A Family? New Anthropological Views, in RETHINkING THE FamILY: SOME Feminist Questions 25-39 (B. Thorne \& M. Yalom eds. 1982).

18. The sparse rationales offered by courts provide few clues to explain discrepancies in applying statutes. See R.K.S., 10 Fam. L. Rep. (BNA) 1383 (court, rejecting literal statutory reading, held exceptional dispensation of adoption agency investigations for spouses of natural parents inapplicable); Kentucky v. Surrogate Parenting Assocs. (SPA), No. 84-CA-136-MR (Ky. Ct. App. Apr. 26, 1985) (LEXIS, States library, Ky file) (SPA activities barred because violative of adoption statutes; court chastized "obvious subterfuge" to hide fact that infertile wife would have to adopt child), rev' $d, 704$ S.W.2d 209 (Ky. 1986); Baby Girl, 9 Fam. L. Rep. (BNA) 2348 (court refused to adjudicate paternity); Syrkowski v. Appleyard, 122 Mich. App. 506, 333 N.W.2d 90 (1983) (court construed adoption statutes loosely, but paternity statutes strictly), rev'd, 362 N.W.2d 211 (1985) (court decided Michigan Paternity Act should be applied); Doe v. Kelley, 106 Mich. App. 169, 307 N.W.2d 438 (1981) (court condemned parties for inconsistent reliance on some but not other adoption statutes; court did apply adoption statute prohibiting payment for child).

19. For example, the application of adoption statutes is erroneous given the nature of surrogate mother arrangements. Some courts have recognized the uncomfortable fit and have struggled with the fact that a natural father cannot adopt his own child. See, e.g., Kentucky v. Surrogate Parenting Assocs., 10 Fam. L. Rep. (BNA) 1105, 1106 (Ky. Cir. Ct. 1983) (digest of opinion), rev'd, No. 84CA-136-MR (Ky. Ct. App. Apr. 26, 1985), rev'd, 704 S.W.2d 209 (Ky. 1986). Other courts have bifurcated the roles of the initiating parents by considering the statutes applicable because at least the infertile wife must adopt the child. E.g., Kentucky v. Surrogate Parenting Assocs., No. 84-CA-136MR (Ky. Ct. App. Apr. 26, 1985). In effect, these courts have disallowed a "reverse" presumption of legitimacy, which would give the infertile wife automatic maternal rights, derived from the marital status. Other courts have not been troubled by the incongruity; they have essentially ignored the complications and denied the natural father's rights altogether. E.g., RKS, 10 Fam. L. Rep. (BNA) 1383; Baby Girl, 9 Fam. L. Rep. (BNA) 2348; Doe v. Kelley, 6 Fam. L. Rep. (BNA) 3011 (Mich. Cir. Ct. 1980), affd, 307 N.W.2d 438 (Mich Ct. App. 1981); see also Op. Ohio Att'y Gen. No. 83001 (Jan. 3, 1983) (organization may not arrange surrogate contracts because illegal "to . . . knowingly become a party to the separation of a child from its parents"). Such disregard violates Supreme Court pronouncements on the rights of natural fathers. See Caban v. Mohammed, 441 U.S. 380 (1979) (unconstitutional to deny unwed father same right as unwed mother to block adoption of child); Stanley v. Illinois, 405 U.S. 645 (1972) (unwed father entitled to hearing on fitness before children taken from him). 
mother to relinquish parental rights, 4) legitimation by a biological father, and 5) adoption by his wife. ${ }^{20}$ In isolation, each of the five activities appears to fall within rules established in termination, adoption, or child custody cases. By focusing narrowly, however, courts disregard the unique combination of factors. Only a holistic approach to surrogate motherhood arrangements can consistently reach the appropriate result.

By default, surrogate arrangements are being mapped onto a legal system that was not designed to handle the new reproductive technology. Legal mismatching by courts is creating an incoherence which promises to worsen as ad hoc approaches accumulate. ${ }^{21}$ The cumbersome and unnecessary procedures required by states result in excessive state intervention in procreation, superfluous burdens for courts, and extra legal fees for parties involved. Added complications increase the probability of contractual ambiguity, and consequently increase the chances of legal conflict. Controversy or procedural delay may be detrimental to the child. ${ }^{22}$

Judicial treatment suffers from a distorted perspective of surrogate parenting arrangements. ${ }^{23}$ To remedy the distortions, a new framework-and not just new law-is needed.

\section{A New Approach to Procreation}

Current legal analysis begins with the traditional identity of the mother as a given. The new starting point for analysis of childbearing cases should instead be the procreative process itself. Translation of the process into a multi-dimensional matrix allows the new complexities to be ordered

20. See Rushevsky, Legal Recognition of Surrogate Gestation, 7 Women's Rts. L. Rep. (Rutgers Univ.) 107, 109 (1982).

21. Academic proposals for improvement have contributed to the confusion. By starting from the law as applied, scholars have assumed current law's inadequacies. See supra note 4. These proposals, based more on similarities than differences between surrogate mothering arrangements and arrangements contemplated in current legislative schemes, commonly recommend only "minor" modifications. See, e.g., Comment, Contracts To Bear a Child, 66 CAlif. L. Rev. 611, 622 (1978) (surrogate contracts should be legal); Comment, Parenthood by Proxy: Legal Implications of Surrogate Birth, 67 IowA L. REv. 385, 399 (1982) (recommending statutory regulation of surrogate arrangements and legitimacy of surrogate children); Comment, Surrogate Motherhood in California: Legislative Proposals, 18 SAN Diego L. Rev. 341, 384-85 (1981) (California law should be amended to allow natural father to establish paternity).

22. See infra note 74 and accompanying text.

23. Courts' unwillingness to look below the surface in analyzing surrogate cases follows partly from their hasty assessments that surrogate motherhood arrangements violate public policy. See infra note 51 . Such conclusions are based in part on the failure of legislatures to address the issue. Without courts being so overt in their rationales, the judicial objective seems to be to frustrate the use of surrogate arrangements until these arrangements receive legislative approval. Artificial forms of reproduction challenge the public's very notion of family, but neither courts nor elected officials can afford to avoid these explosive issues. Because the technology exists and surrogate mothers are available, the use of the new technology is inevitable and cases will arise with greater frequency. See Griffin, Womb for Rent, A.B.A. Student LAw., Apr. 1981, at 28, 47 (statistics of requests for surrogate mothers). 
by new rules. A diagram of the procreative process, divided into stages with definite transition points, provides the basis for legal analysis: ${ }^{24}$

SURROGATE MOTHERHOOD

\begin{tabular}{|c|c|c|c|c|}
\hline $\begin{array}{l}\text { PROCREATIVE } \\
\text { STAGES } \\
\text { (transition } \\
\text { points) }\end{array}$ & $\begin{array}{l}\text { (1) } \\
\text { Child } \\
\text { Initiating } \\
\text { Stage } \\
\text { (con }\end{array}$ & \begin{tabular}{|c|} 
(2) \\
Preparation \\
Stage
\end{tabular} & \begin{tabular}{|c|} 
(3) \\
Gestation \\
Stage \\
\end{tabular} & $\begin{array}{l}\text { (4) } \\
\text { Child } \\
\text { Raising } \\
\text { Stage } \\
\text { th) }\end{array}$ \\
\hline $\begin{array}{c}\text { ACTIVE } \\
\text { PARTICIPANTS }\end{array}$ & $\begin{array}{c}\text { natural father } \\
\text { wife }\end{array}$ & \begin{tabular}{|c|} 
natural father \\
wife \\
surrogate mother \\
physician \\
lawyer
\end{tabular} & $\begin{array}{c}\text { surrogate mother } \\
\text { child }\end{array}$ & $\begin{array}{l}\text { natural father } \\
\text { wife } \\
\text { child }\end{array}$ \\
\hline
\end{tabular}

The matrix gains a dimension when the respective parties in each stage are assigned certain rights and obligations. The table clarifies the relationships between procreative parties, and as a legal framework, provides a way for the rights of parties to change within the process. The increased variability in the assignment of rights and obligations would reduce arbitrariness and mistake in judicial decisionmaking.

The necessary task for courts and legislatures is to provide relief to what has traditionally been depicted as a flat process. The full process of birthing is no simple biological linearity ${ }^{25}$ In this regard, the juxtaposi-

24. Although the divisibility of procreative tasks is hardly relevant in a traditional marriage and child raising setting, it is the essence of surrogate mothering. The four stages of procreation in the first row must always occur, and clearly discernible transition points unambiguously divide them. $C f$. Robertson, Procreative Liberty and the Control of Conception, Pregnancy, and Childbirth, 69 VA. L. REv. 405, 410 (1983) (division of procreation into "genetic, gestational, [and] social components"). After parents make the initial decision to bring a child into existence, they may contract for third party assistance in the process-from a physician, lawyer, and surrogate mother. The effective date of the contract is the first legal marker. Following agreement on terms, the parties perform their various roles in the preparations for the biological beginnings of the child. The husband donates sperm, with which the surrogate mother is artificially inseminated. The second clear legal marker is the point of actual implantation in the surrogate mother's womb, and this begins her term of gestation. Gestation culminates in birth, the third legal marker.

The first row thus represents the child's creation as a continuum, segmented by tasks. The second row maps out the parties active at each stage. Note that the diagram depicts physical activity, rather than legal rights.

25. Judicial reduction of motherhood to biological factors is symptomatic of historic male control of public institutions; society has been infused with male interpretations of motherhood. Mary O'Brien, midwife turned theorist, describes how in her medical training, men taught

about the stages of gestation and the stages of labour . . . . Men have brought to obstetrics the sense of their own alienated parental experience of reproduction, and have translated this into the forms and languages of an 'objective' science. Thus, the process appears as a neat unilinear affair going on in women's bodies in a rather mechanistic way.

M. O'Brien, The Politics of Reproduction 45-46 (1981). Courts have adopted this flat view of mothering, beginning and ending with the physical realities of gestation, as their model. See, e.g., West Virginia ex rel. J.L.K. v. R.A.I., II, 294 S.E.2d 142 (W. Va. 1982) (extensive discussion of 
tion of all the stages in the form of a flat table is misleading. Although the process takes place along a temporal continuum-the chronology progresses from stage one to stage four-it is a multi-dimensional continuum.

Of the four procreative stages, the pregestational stages are the critical additions to judicial analysis. The psychological dimension of procreation precedes and transcends the biology of procreation. Motherhood can be a product of both mental and physical conception; reductionist modes of legal reasoning have ignored this fullness. ${ }^{26}$ For the initiating parents, insofar as biology has obfuscated psychology, parental rights have been damaged by misperceptions of parenthood. ${ }^{27}$ Applying a more inclusive view of the underpinnings of parenthood, the next four sections designate legal rights of parties within each of the four stages.

\section{Stage One: The Ghild Initiating Stage-Psychological Aspects of Procreation}

\section{A. The Dimensions of Mental Conception}

In slighting mental elements of procreation, judicial analyses of surrogate motherhood cases seriously underestimate the critical role of stage one. ${ }^{28}$ Although the deficiency is especially apparent in procreative ques-

whether wife who lived separate and apart from husband for one year prior to birth could accuse person other than husband of being father of child).

26. See infra note 40 and accompanying text. Biological emphasis takes account of psychological factors in only one respect. There is evidence that a mother's biological state during gestation prompts certain psychological reactions to the child. Hormonal releases during parturition and nursing affect the brain and may create maternal dispositions in mothers. See, e.g., Pedersen, Asher, Monroe \& Prange, Oxytocin Induces Maternal Behavior in Virgin Female Rats, 216 ScIENCE 648 (1982); see also Caban v. Mohammed, 441 U.S. 380, 405 n.10 (1979) (Stevens, J., dissenting) (referring to unique mother-child bonding). However, the significance of induced postpartum maternal behavior is debated, and evidence of psychological bonding is not sufficiently clear to give automatic rise to maternal rights. See N. Chodorow, The Reproduction of Mothering 26-30, 29 (1978) ("Conclusions about the biological basis of parenting in humans can only be speculative.").

To the extent that physical pregnancy creates psychological bonding, the biology of motherhood may appropriately be given additional weight in the rights and obligations calculus of courts. It is unclear how biologically-induced "intent" to maintain a parental relationship with a child should be balanced with purely psychological intent.

27. In some recent cases, the emphasis on biology has been set aside to accommodate the use of artificial insemination. Paternity in these cases vests at the point of the husband's consent to artificial insemination, rather than at the point of biological conception. See R.S. v. R.S., 670 P.2d 923 (Kan. Ct. App. 1983); K.S. v. G.S., 182 N.J. Super. 102, 440 A.2d 64 (1981). Courts justify this shift in analysis as necessary for the process, which "usually requires a series of treatments over a period of time until pregnancy occurs . . . ; once the husband consents it should not be necessary for the wife and treating physician to continually go back to the husband to determine if his consent is continuing." Reproductive Law Rep., supra note 6, at R136. More procreative options make the element of choice more important.

28. The major exception in surrogate cases has been the final decision in Surrogate Parenting Assocs. v. Kentucky, 704 S.W.2d 209 (Ky. 1986). Pregestational factors recognized by the court included the fact of agreement before (biological) conception, the wife's problem of infertility, and in that context, reference to the constitutional right to bear and beget. 
tions, family law has characteristically shunned mental elements. ${ }^{29} \mathrm{Al}-$ though the emergence of biologically based doctrines in family law may be explicable, ${ }^{30}$ other legal disciplines reveal the importance of acknowledging the mental component of events. In criminal law, sanctions for acts do not normally follow without intent. ${ }^{31}$ In contract law, intent manifested by a promise and subsequent reliance provides the basis for enforceable agreements. ${ }^{32}$ Typically, the mental element is the pivotal element in determining legal outcomes. ${ }^{33}$

Courts in surrogate motherhood cases have given little consideration to the motivations of initiating parents. Prior to physical conception of a child, the beginnings of a normal parent-child relationship can come from mental conception, the desire to create a child. ${ }^{34}$ When the child's exis-

29. See, e.g., supra note 25; infra note 42; see also H. KRAUSE, Illegrtimacy: LAw and Social. Pol.ICY 69 (1971) ("[B]iological relationship is the test that has been used-since time immemorial-in our and other cultures for the fixing of support and other familial obligations, and it is biological relationship that underlies and is traced by legal relationship."). But see Boskey \& McCue, Alternative Standards for the Terminations of Parental Rights, 9 SETON HaLl L. REv. 1, 4 (1978) (noting that while postnatal parent-child relationships traditionally received limited analysis, recent trend has been "increasing judicial reliance upon psychological principles"); Note, Psychological Parents vs. Biological Parents: The Courts' Response to New Directions in Child Custody Dispute Resolutions, 17 J. FAM. L. 545 (1979).

30. Biology has been a tempting indicator for courts for several reasons. First, the physical realities of sperm donation, egg donation, and gestation are easier to ascertain and analyze than the mental aspects of birth. Second, in contrast to personal psychologies, biology has an inherent permanence. Traditionally, the genetic origins of a child arose immutably from a particular father and a particular mother. By latching rights and obligations onto fixed biological traits, courts have been assured longterm validity of their rationales. Third, in family disputes over a child, a judge is typically faced with a fait accompli: the child exists, even as a fetus in the womb. Because the procreative process has progressed to the point where the biological links have been forged, the judge always can and usually will focus on the biological facts of the relationships at stake.

31. The common law requirement of mens rea came from the notion that guilt arose from a state of mind. While intent in criminal law is admittedly complex, it is at least clear that intent is a material element of the crime. See MOdel. Penal Code $\$ 2.02$ commentary (1985).

32. See 3 A. Corbin, Corbin on Contracts $\$ \S 536,538$ (1960).

33. For example, patent and copyright protection extends to embodied ideas. See 2 E. LIPSCOMB, Lipscomb's Walker on Patents $\$$ 6:3 (3d ed. 1985); M. Nimmer, Cases and Materials on COPYRIGHT 1, 30 (3d ed. 1985). Analogously, thoughts of initiating parents which become embodied in the creation of a child parallel the mental element at the root of intellectual property protection.

Paradoxically, the first judicial pronouncement credited with founding copyright in Englishspeaking countries analogized protections for creations of the mind with protections for creations of the body. Legend has it that in 567 A.D., ecclesiast Columbia copied his teacher Finnian's psalter. The adjudicating King Diarmud settled the controversy in favor of Finnian, and said, "To every cow her calf." It is ironic that the notion of literary property should have been birthed by a notion of motherhood as construed by biology. R. Wincor \& I. Mandell, Copyright, PAtents AND Trademarks: The Protection of Intellectual and Industrial Property 2-3 (1980).

34. Webster's Dictionary distinguishes the two relevant meanings of the word "conception": (1) the act of becoming pregnant, formation of a viable zygote, and (2) the originating of something in the mind. Webster's Third New International Dictionary 469-70 (1981).

Marriage as an institution was designed partly to make the distinction between mental and physical conception irrelevant. This irrelevance applies to normal procreation between two parties outside of marriage as well, with few exceptions. See In re L. Pamela P. v. Frank S., 59 N.Y.2d 1, 449 N.E.2d 713,462 N.Y.S.2d 819 (1983) (father ordered to pay child support despite mother's deception that she was using contraceptives). However, the distinction between mental and physical conception becomes evident and important when different parties are involved in different stages of artificial procreation. 
tence begins in the minds of the desiring parents, biological conception of the child declines in importance relative to psychological conception with respect to the full life of the child. The mental concept of the child is a controlling factor of its creation, and the originators of that concept merit full credit as conceivers. The mental concept must be recognized as independently valuable; it creates expectations in the initiating parents of a child, and it creates expectations in society for adequate performance on the part of the initiators as parents of the child. The rights and obligations $^{\mathbf{3 5}}$ of initiating parents should reflect their position of relative importance. $^{38}$

Although a reproductive act does not always involve an intent to create a child, the use of reproductive technology is an unambiguous indicator of intent. Users of such technology intend to produce a child and intend to accept the responsibility of caring for it. ${ }^{37}$ Sanctions can follow destructive intent, as in criminal law, and benefits can follow productive intent, as in contract law. An intent to create and care for a child, acted upon through artificial procreation, is a positive intent that should be protected by law. Use of the surrogate method, manifesting procreative intent, should invoke the legal presumption that the child belongs to the intenders. ${ }^{38}$

The most egregious distortion in surrogate cases is the failure of courts to acknowledge the role of the infertile wife. ${ }^{39}$ Although the infertile wife

35. In general, the scope of rights and obligations encompasses the ability to treat a child as one's own. Once the child is born, this ability includes the right to raise the child and the obligation to provide for the child.

36. The tendency to underemphasize the initiating role in procreation is exaggerated by judicial application of statutes which are designed for postnatal activities, such as adoption, rather than prenatal activities. See supra note 19 and accompanying text. Indeed, the historical inclination has been conceptually to fuse women's prenatal and postnatal contributions to parenting. See D. DiNNERSTEIN, The Mermaid and the Minotaur: Sexual Arrangements and Human Malaise 149 (1976).

37. In other contexts, where there is ambiguity as to intent, courts look to the performance of the act as a reflection of intent. See, e.g., O'Brien v. Cunard Steamship Co., 154 Mass. 272, 28 N.E. 266 (1891) (act of submitting to vaccination indicated intent to allow surgeon to vaccinate). The choice of procreative process-artificial reproduction is much more cumbersome to carry out than the proverbial one night stand-can be a clear reflection of intent.

38. See also Regulation of Alternative Reproduction-Looking Backward and Looking Ahead: Hearings Before the Subcomm. on Investigations and Oversight of the House Comm. on Science and Technology, 98th Cong., 2d Sess. 181 (1984) (statement of Lori Andrews) (advocating for public policy reasons that prenatal intent govern surrogate cases).

39. Nowhere in its entire discussion does the court in In re Baby Girl mention the infertile wife. 9 Fam. L. Rep. (BNA) 2348 (Ky. Cir. Ct. 1983). She is essentially regarded as not being a party to the arrangement; the triad in consideration consists of the natural father, the surrogate mother, and her husband. However, the arrangement more appropriately should be understood to involve a different triad: the natural father, the surrogate mother, and the infertile wife. In Syrkowski v. Appleyard, 420 Mich. 367, 373, 362 N.W.2d 211, 213 (Mich. 1985), the court's discussion of "born out of wedlock" reveals the inability of current legal doctrine to consider the new complexity of surrogate arrangements. Although the court rests its final holding on the premise that the surrogate child is not the issue of the surrogate mother's marriage, making the Paternity Act applicable, the court never considers that in one sense the child does issue from a marriage-the biological father's marriage. The presumption of motherhood and the court's narrow reading of statutes is sufficiently powerful to keep this other marital context from being considered. Thus, the court utterly fails to appreciate that the 
has no biological connection to the child, she, in partnership with her husband, is responsible for initiating the surrogate process. Understanding the infertile wife's role as mother makes clear that surrogate arrangements render the biological link obsolete as the legal determinant of "mother."40 There are two maternal actors in surrogate arrangements: the intending mother who initiates the biological process and later fulfills the social process of child rearing, and the surrogate mother who carries out the biological process and then ends her role as mother. ${ }^{41}$ Where the birthing party is no longer the unambiguous mother, parental rights and obligations should not be determined by traditional legal formulae. ${ }^{42}$

surrogate arrangement contributes to family integrity. See also Kentucky v. Surrogate Parenting Assocs., 10 Fam. L. Rep. (BNA) 1105, 1106 (Ky. Cir. Ct. 1983) ("The natural father and the surrogate mother are the parties to the transaction and so it must be analyzed in that framework.").

40. Biology and psychology are both critical to procreation. Variations between these factors yield three versions of procreation: 1) psychological intent and the biological act overlap-this is the normal case of parents who want a child and create it alone; 2) the biological act takes place without prior psychological intent-this is when two parents are faced with a pregnancy they may not have initially desired, see In re K, 535 S.W.2d 168 (Tex. 1976) (child as "biological consequence of erotic ecstasy on a summer night"); 3) psychological intent and the biological act are separate-this case occurs when the initiating parents enlist the assistance of a surrogate mother to produce a child.

Scenarios one and two, capturing childbirth throughout history, allowed biology to be the appropriate determinant of the mother's identity, even when biology was not the only factor involved. Mental conception was always joined with physical conception in the same mother. When there was no mental conception, there was no competing candidate for the title of mother. It has been legally advantageous to emphasize biology in the past, see supra note 30 , and the biological link has represented the psychological link by proxy. However, the convenient overlap of psychological intent and biological fact does not exist with newly bifurcated procreative roles.

41. Traditional concepts of motherhood would characterize this division of roles as "unnatural." However, the psychosocial basis of motherhood suggests that such a limited definition of "natural" would deny the versatility inherent in human nature. See, e.g., E. Maccoby \& C. JackLiN, ThE Psychology of Sex Differences 354, 374 (1974); M. Mead, Sex and Temperament in Three Primitive Societies 279-81 (3d ed. 1963); Dornbusch, Afterword, in The Development of SeX DifFERENCES 214-15 (E. Maccoby ed. 1966).

Feminists have spun a variety of theories around the less restrictive view of womanhood and, despite divergent extrapolations, the central premise is well-established: It is erroneous to assume that women are destined to be mothers or that biological mothers have a monopoly on child rearing. See, e.g., N. Chodorow, supra note 26, at 11-39; S. Firestone, The Dialectic of Sex: The Case For Feminist Revolution 8-11 (1970); K. Millett, Sexual Politics 26-33 (1970). Kate Millett's idea of separating the two central functions of the family-socialization and reproduction, id. at 35-can be extended to include a separation of roles within reproduction as well. As a remedy for a social problem, adoption has been a way to cope with mothers who have chosen postnatally to abdicate their responsibilities. As a remedy for individual inability, mothers should be able to collaborate prenatally to create a child.

It is neither unnatural for a mother to relinquish her child to another caring mother nor unnatural for one mother to acquire a child gestated by another mother. The fact that the role separation occurs within the procreative process itself is a new extension of old practices. The philosophy of sharing implicit in surrogate arrangements is an ancient and recurring one. See, e.g., S. ShaHAR, ThE Fourth Estate: A History of Women in the Middle Ages 183-85 (1983) (wetnurses); A. RABIN, Growing UP IN THE KIBBUTZ (1965) (Jewish child cooperatives). As with child rearing, child bearing should be free from constraints imposed by the traditional, moral exclusivity of sexual relations.

42. The tendency to devalue the position of the initiating mother and, consequently, to give the surrogate mother greater legal standing has deep cultural roots. Western society's historical tendency has been to squeeze the woman's role of mother into a biological pigeonhole. See, e.g., N. Chodorow, supra note 26, at 3-7. Despite a professed search for unbiased justice, Western law has 


\section{B. Constitutional Rights of Procreation and Conception}

As courts have struggled to define the parameters of procreative choice, the right of procreation has received its most extensive legal expression as a right not to procreate. ${ }^{43}$ More broadly, the right of privacy has been held to include the preservation of procreative potential, ${ }^{44}$ but not the assurance of procreative opportunity. ${ }^{45}$ Although doctrinal protection of the choice to procreate is incomplete, court decisions suggest that procreative choice should be safeguarded because parents have a fundamental personal interest in producing children. ${ }^{46} \mathrm{~A}$ logical analogue to this protection

followed the myopia of Western society in focusing on the biological discrepancy between, rather than the psychological similarity of, maternity and paternity. A juxtaposition of maternity and paternity most clearly reveals this bias.

Maternal rights have sprung from a biological certainty in the law. See supra note 1 and accompanying text. Through engrained habit, the use of biology to define motherhood in the law has assumed a significance greater than that due the limited shorthand it actually is. By contrast, paternal rights have been a much more discretional part of the law. Under the guise of the presumption of legitimacy, see supra note 10 , it was a short step to refine tests of paternity into distinctions on the basis of legitimacy. See P. Tisset, Présomption de Paternitế (1921). Supported by the tenet that a mother and child alone did not constitute a sufficient socioeconomic unit, see B. MaLINowSKI, SEX AND REPRESSION IN SAvAGE Soctety 213 (1927), marriage manipulated the ambiguous paternal connection to create certain and uncertain paternity, "legitimately" denying reality for the sake of morality. See H. KRAUSE, supra note 29. Whereas maternity grew into an obligation to the child, paternity grew into a right to the child. The demands of motherhood were natural, while the role of fatherhood was more voluntary. See E. Borneman, Das Patriarchat 359 (1975).

Despite the adage that "maternity is a matter of fact, and paternity is a matter of opinion," the dichotomy is less valid and more transparent today than ever. Current trends have curbed the voluntariness of fatherhood with actionable orders of filiation for child support. See generally C. KASTNER \& L. Young, In the Best Interest of the Child: A Guide to State Child Support and Paternity Laws (1981). At the other extreme, contraceptives have added an element of volition for women. To further equalize parental rights, there has been a movement to rebut the presumption of maternal preference in child custody cases. See Foster \& Freed, Life with Father: 1978, in Fathers, Husbands and Lovers: Legal Rights and Responsibilities 139, 143-60 (S. Katz \& M. Inker eds. 1979). Now artificial forms of reproduction offer to tip the scales further into equilibrium by allowing motherhood to be more a matter of choice and design.

43. The right not to procreate arises from a penumbra of constitutional rights under the heading of privacy. See Griswold v. Connecticut, 381 U.S. 479 (1965) (use and distribution of contraceptives protected by right of privacy); Roe v. Wade, 410 U.S. 113 (1973) (abortion rights given limited protection by right of privacy). Whereas women may seek and receive assistance from others in terminating a pregnancy, women are not as free to seek and receive assistance in initiating and carrying through a pregnancy. See infra note 45.

44. See Skinner v. Oklahoma ex rel. Williamson, 316 U.S. 535, 541 (1942) (sterilization of habitual criminals violates equal protection clause).

45. See Beal v. Doe, 432 U.S. 438 (1977) (upholding state exclusion of welfare funding for nontherapeutic abortions); Maher v. Roe, 432 U.S. 464 (1977) (state may choose to subsidize childbirth without subsidizing nontherapeutic abortions). There has been no Supreme Court holding on artificial forms of reproduction. Only Justice Brennan would have granted certiorari in Doe v. Kelley, 106 Mich. App. 169, 307 N.W.2d 438 (1981) (fundamental interest to bear and beget does not extend to contract and compensation in surrogate motherhood), cert. denied, 459 U.S. 1183 (1983).

46. E.g., Paris Adult Theatre I v. Slaton, 413 U.S. 49, 65 (1973) ("privacy right encompasses and protects . . family, marriage, motherhood, procreation and child rearing"); Stanley v. Illinois, 405 U.S. 645, 651 (1972) ("rights to conceive and to raise one's children"); Meyer v. Nebraska, 262 U.S. 390,399 (1923) ("right of the individual . . to marry, establish a home and bring up children"). 
would be recognition of a fundamental interest in procuring assistance to overcome a personal inability to procreate.

Procreation has anthropological and sociological significance supporting its designation as a fundamental right. No other creative function ranks with the process of procreation in its importance to individuals and to society. The impetus to procreate is fostered both biologically through hormonal impulses and psychologically through enculturation..$^{77}$ A constitutional right to procreate is in part a tacit acknowledgement of the internal and external pressures working on most individuals to that end.

If the right to procreate is to be fully protected, it requires the assurance of certain derivative rights. ${ }^{18}$ Obstacles to the use of surrogate motherhood are excessive even if they are indirect. At the very least, state interference which effectively prohibits procreation by the initiating parents must be subject to strict scrutiny. ${ }^{49}$ The fundamental interest of begetting a child ${ }^{50}$ should not be abrogated without proof that preservation of a compelling state interest justifies the denial of the right and can be achieved by no less restrictive means. Statutes currently applied to surro-

47. See E. Pohlman, The Psychology of Birth Planning 35-81 (1969) (discussion of extent and sources of parents' desires for children). One court in a surrogate case acknowledged the existence of "forces which motivate human beings seeking to have children," but it concluded that "[t]o assume [the natural father's] intentions are a pure and a noble attempt to fulfill the wish to have a child in his family is not sufficient for reaching a result in this appeal." Syrkowski v. Appleyard, 122 Mich. App. 506, 513, 333 N.W.2d 90, 93 (1983) (Paternity Act not extended to surrogate mother case), rev'd, 420 Mich. 367, 362 N.W.2d 211 (1985); see also Surrogate Parenting Assocs. v. Kentucky, 704 S.W.2d 209 (Ky. 1986).

48. An analogy can be drawn to the protection of free speech from chilling effects, or the protection of distribution and sales of contraceptives. See Griswold v. Connecticut, 381 U.S. at 482-85.

49. The state's need to infringe on an individual right must be balanced with the individual's interest in preserving that right. The right of procreation has particular relevance for potential parents who, by the lottery of nature, are biologically incapable of procreating. Infertility is a debilitating medical infirmity. Menning, The Psychology of Infertility, in INFERTILITY: Diagnosis and MaNAGEMENT 17 (J. Aiman ed. 1984) (describing infertility as "a state of involuntary childlessness, the thought of which can pervade every waking moment and make decisions for the future next to impossible"). Striking fifteen percent of all married couples in 1976, infertility is increasing. In approximately half of the cases, the woman is unable to produce offspring. See L. ANDREws, NEW CONCEPTIONS: A Consumer's Guide to THE NEWEST INFERTILity TreatMents 2-3 (1985). Long waiting lists are making non-biological alternatives, like adoption, increasingly difficult. Lorio, Alternative Means of Reproduction: Virgin Territory for Legislation, 44 LA. L. REv. 1641, 1641-42 (1984).

50. The Supreme Court has articulated the right as one to "bear or beget." Carey v. Population Servs. Int'l, 431 U.S. 678, 685-87 (1977); Eisenstadt v. Baird, 405 U.S. 438, 453 (1972). To beget is defined, "to procreate as the father." WEBSTER's Third NEW INTERnational DictionarY 198 (1981). However, an infertile mother can also beget, even if she cannot bear. The infertile mother finds herself in much the same position as the natural father has throughout time found himself. Similarly incapable of direct experience with child creation, see, e.g., M. O'BrIEN, supra note 25, at 51-53 (discussing "alienation of the male seed"), the initiating and intending mother in surrogate arrangements must also rely on a mental connection to claim her child. Courts readily spanned the presumption of legitimacy for fathers across non-biological linkages to create paternity, even when there was no intent to raise a child or when subsequent marriage invoked the presumption. See supra note 10 (discussing presumption of legitimacy). Precisely when there is an intent to raise the child, non-biological connection should constitute legal maternity. 
gate mother arrangements are neither narrowly drawn nor expressly linked to prenatal public policy concerns. ${ }^{\text {s1 }}$

Included in a right to procreate is a right to conceive. ${ }^{.2}$ By including abortion under the rubric of protected privacy, courts uphold the right to conceive as separable from the obligation to procreate. Abortion, then, is a right to conceive followed by a protected option-a right not to procreate. Surrogate motherhood is the inverse: a right to conceive that should also be followed by a protected option-a right to procreate. In the abortion case, the mother's conception is likely only biological in origin. In the surrogate mother's case, the initiating mother's conception is only mental. Different kinds of protection are required for conceivers to realize different kinds of procreative intent. ${ }^{\text {ss }}$

Courts in abortion cases must balance the rights of a mother and a child, whereas courts in surrogate cases must balance the rights of two mothers and a child. ${ }^{54}$ However, in both cases, the fundamental right of conception as a predicate of the right to procreate is at stake. Because even infertile mothers can exert their right of psychological conception, they,

51. For example, courts impute adoption public policy concerns, such as "baby bartering" and adoption consent prior to birth, to surrogate arrangements. See generally Rushevsky, supra note 20, at $113-19$.

Particularly extensive debate surrounds compensation for the surrogate mother's gestational services. See, e.g., Murray, Who Owns the Body? On the Ethics of Using Human Tissue for Commercial Purposes, 8 I.R.B. 1-2 (Jan.-Feb. 1986). The arguments reflect two simultaneous but opposing valuations of motherhood: moral veneration and practiced degradation. On the one side, the traditional sacredness of the mother-child relationship makes even a voluntary separation objectionable. See, e.g., Watson v. Watson, 134 S.C. 147, 159; 132 S.E. 39, 43 (1926) ("Icjourt will assume that no good mother will very readily and willingly give up permanently her baby"). The negative connotations of worldly mammon make parting coupled with payment even more objectionable. The Attorney General of Louisiana, in response to an inquiry, stated that '[t]here may be no payment to a 'middleman' or "broker," " nor could the surrogate mother be paid anything other than necessary prenatal expenses. See Op. La. Att'y Gen. 83-869 (Oct. 18, 1983). On the other side, the historical failure to value domestic work of mothers and housewives has contributed to the sense that gestation has no value as a form of productive labor. See Frauen IN DER OfFEnsive, LOHN Fǘr DIE HAUSARBert OdER: AUch BERUFSTÄTIGKEIT MACHT NICHT FREI (1974) for arguments supporting valuation of domestic labor. More specifically, surrogate contract lawyer Katie Brophy claims, "[a] surrogate is pregnant twenty-four hours a day for nine months. She deserves to be paid for her time and energy-not to mention the physical suffering she endures and the risk she undertakes for the adoptive parents' benefit." Griffin, supra note 23 , at 31 .

The productive value of gestation should be acknowledged, and the surrogate mother should be allowed to offer her service in return for adequate compensation. See generally Comment, BabySitting Consideration: Surrogate Mother's Right To "Rent Her Womb" for a Fee, 18 Gonz. L. REv. 539 (1983).

52. See, e.g., Robertson, supra note 24 , at 405 (conception discussed as separate, valuable aspect of procreative freedom).

53. For surrogate cases, the procreation option should be protected at least to the extent that all collaborating parties agree to the outcome. However, if a conflict arises between the surrogate mother and the initiating parents, current interpretations of the right of procreation would likely lead to inequitable judicial treatment of the initiating parents as compared to other parents. Courts recognize and try to preserve the procreative intent of mothers who desire abortions. By contrast, courts refrain from enabling the procreative intent of initiating parents to be realized.

54. Rights of natural fathers in both cases are not negligible. See supra note 19. 
too, have a procreative right that courts should preserve. Conscious and intentional exertion of the right to procreate should be accorded more protection than an accidental and unintended action of procreation. The ability to exert a right of conception in stage one should invoke a protected right of child raising in stage four. ${ }^{65}$

\section{Stage Two: The Preparation Stage-Conscientious Third PARTY INVOLVEMENT}

In stage two the procreative process moves from the purely private realm of the initiating parents to the quasi-public realm of third party involvement. Preparatory collaboration in this early period is critical in assuring a positive outcome of the surrogate arrangement. The surrogate mother who the initiating parents engage in the process should be both physically and psychologically fit. ${ }^{86}$ Because the assessment of an appropriate surrogate mother may be difficult and complex, initiating parents may shift the onus of careful selection and preparation onto legal and medical professionals. ${ }^{57}$

55. See infra text accompanying notes $67-70$.

56. The initiating parents have an interest in the surrogate mother's lifestyle both before and during stage three. Scientific studies indicate that a fetus is affected by pregestational behavior. $R$. Blank, Redefining Human Life: Reproductive Technologies and Social Policy 132 (1984). Because the surrogate mother's right of personal integrity would largely obviate the enforcement of contractually prescribed behavior for both stages two and three, see infra notes 61-62, it behooves the initiating parents to procure the help of a responsible surrogate mother. Under extreme circumstances, misrepresentation by the surrogate mother about her lifestyle prior to entering the arrangement might justify a damage award for initiating parents.

57. Lawyers and physicians, equipped with experience and expertise, should be included in surrogate arrangements. Informal agreements among parties who neglected to seek professional guidance have, in several instances, led to undesirable misunderstandings and conflicts. See, e.g., C.M. v. C.C., 152 N.J. Super. 160, 377 A.2d 821 (1977) (semen donor granted visitation rights against mother's wishes in private artificial insemination arrangement); Jhordan C. v. Mary K., No. A027810 (Cal. Ct. App. Mar. 28, 1986) (LEXIS, States library, Cal file) (same; court emphasizing value of professional assistance). Traditional standards of negligence for professional actors would create incentives for responsible selection and preparation of the surrogate mother. Accord Frankel, Artificial Insemination and Semen Cyrobanking: Health and Safety Concerns and the Role of Professional Standards, Law and Public Policy, 3 Legal MED. Q. 93, 97-98 (1979). Such incentives would not be misplaced because responsible service is especially critical to the lives of the surrogate mother and the child.

Standards applied by a surrogate matching group in Maryland entail "very strict criteria. Many women contact us wanting to be surrogates, but few pass the first screening." Findlay, Case Will Redefine 'Mother,' USA Today, Apr. 17, 1986, at 1A, col. 3. Surrogate Parenting Associates in Kentucky requires medical screening of potential surrogate mothers. See Note, In Defense of Surrogate Parenting: A Critical Analysis of the Recent Kentucky Experience, 69 KY. L.J. 877, 894 (1980-1981). The Kentucky Attorney General would place the risk of harm on the surrogate mother as follows:

The surrogate and her husband agree to assume all risks incident to the pregnancy, including the risk of death. The natural father buys a term insurance policy on the surrogate's life and agrees to pay for her medical expenses.... If any of the harm done to the surrogate mother was a result of some action by the physician, the surrogate could bring a medical malpractice action.

Op. Ky. Att'y Gen. 81-18 (Jan. 26, 1981). A statutory requirement of at least one previous pregnancy 
Lawyer, physician, and surrogate mother enter the arrangement by contract. This formalized procedure signifies commitments and creates expectations. ${ }^{58}$ However, despite the contractual relationship of the procreating parties, the balance of rights and obligations goes beyond the express contractual terms. To preserve the integrity of child creation, the procreative agreement cannot be confined to the four corners of a formal document.

\section{Stage Three: The Gestation Stage-Inviolability of Biological MOTHERHOOD}

Despite the participation of numerous parties in the procreative process, stage three is the domain of the surrogate mother. Although the activity in a surrogate arrangement prior to biological conception may differ from that in natural processes, the gestational stage in surrogate motherhood is essentially the same as in traditional motherhood. Courts must be willing to guarantee the surrogate mother the same rights during pregnancy afforded natural mothers.

Once the embryo is implanted in the womb of the surrogate, the process enters a realm of privacy which entails substantial personal freedom for the gestating mother. ${ }^{59}$ The inviolability of this personal realm prohibits the enforcement of the surrogate contract through specific performance during gestation. ${ }^{60}$ Damage remedies against the surrogate mother for

for a woman who offers to be a surrogate mother would be justifiable to help ascertain her physical ability to carry the child as well as her psychological ability to part with the child.

58. To ensure clear agreement among the parties, the filing of consents by the initiating mother as well as the surrogate mother's husband and perhaps also children would be an appropriate requirement during this stage. In addition, states may wish to require a fee at the time of filing in order to finance follow-up studies of surrogate arrangements. Sufficiently little is known about the social and emotional effects of surrogacy that such a study would enable the state to provide on-going protection in accordance with documented need.

59. A gestational mother's rights are limited only by the rights of the fetus. See, e.g., Jefferson v. Griffin Spalding County Hosp., 247 Ga. 86, 274 S.E.2d 457 (1981) (Jehovah's Witness ordered to submit to Caesarean section to save child). Cigarette smoking is not recognized as a violation of fetal rights, although some studies have shown that it is potentially harmful. R. BLANK, supra note 56, at 138-39. In a few isolated cases, mothers have been found guilty of neglect during pregnancy. See In re Gentry, 142 Mich. App. 701,369 N.W.2d 889 (1985) (state took temporary custody of child when mother's drug addiction resulted in withdrawal symptoms); In re Baby X, 97 Mich. App. 111, 293 N.W.2d 736 (1980) (same). Heroin addiction cases are the tip of a difficult iceberg; courts increasingly will have to ascertain when mothers' lifestyles impinge on their fetuses' well-being. "Although the causal nature of these environmental factors in many cases remains tentative and inconclusive and appears to be interrelated with the mothers' physiological constituency, the evidence of fetal damage resulting from the behavior of the mother is mounting." $R$. BLANK, supra note 56, at 132 . Most understood are the effects of poor nutrition, alcohol consumption, drug abuse, and smoking. Id. But cf. Note, The Creation of Fetal Rights: Conflicts with Women's Constitutional Rights to Liberty, Privacy, and Equal Protection, 95 YALE L.J. 599 (1986) (importance of protecting rights of pregnant women despite competing fetal rights).

60. But $f f$. infra notes $67-70$ and accompanying text (desribing stage four, postgestation rights). For a different analysis resulting in a similar outcome of restricting specific performance for the surrogate mother to postgestation, see Note, Rumpelstiltskin Revisited: The Inalienable Rights of 
nonperformance or breached performance must be severely limited to preserve the fundamental rights of privacy and procreative autonomy. The terms of the contract should serve primarily as indications of the parties' intent, including a willingness on the part of the surrogate mother to abide by the terms. ${ }^{62}$ However, punishing the surrogate mother for "inadequate" birth is misplaced in the traditional scheme of maternity, which accords pregnant women the freedom to lead their own lives without fear of sanction. ${ }^{62}$

No state to date has chosen to monitor individual families for minimum standard pregnancies. ${ }^{63}$ A surrogate mother, no more a machine and no less a human, should not be held to a higher standard of procreation than a natural mother. ${ }^{64}$ The surrogate mother cannot be made to bear the burden of human procreative fallibility. Were the initiating parents capable of producing a child alone, they would have no guarantee that their

Surrogate Mothers, 99 HARV. L. REv. 1936 (1986).

61. Some conditions of a contract would clearly be excessive, such as an option of abortion at the discretion of the initiating parents. Even in marginal areas, the rights of the surrogate mother would usually overcome the interests of the initiating parents. For example, a decision by the surrogate mother to smoke cigarettes during stage three should not be held against her, despite clauses in the contract forbidding such activity. Surrogate contracts typically include terms restricting the ability to absorb undesirable substances. See 1 S. Schatkin, Disputed Paternity Proceedings $\S 1.06$ (4th rev. ed. 1985) (sample surrogate mother contract).

Courts have designated certain rights of the mother as inalienable rights. See Planned Parenthood v. Danforth, 428 U.S. 52 (1976) (protecting women's right to abort against spousal objection). The surrogate mother's right to abort should be preserved, despite any contractual arrangement. As part of the overall arrangement, initiating parents must assume the risk that the surrogate mother will not carry the child to term. Should the surrogate mother decide to abort, the extent of initiating parents' remedy would be that compensation for the surrogate mother be limited to pregnancy expenses prior to the abortion. Conversely, if for any reason the initiating parents feel that the child should be aborted, the surrogate mother should have the right to bring the child into the world. At this point, possessory rights to the child should vest in the surrogate mother, who assumes them when she overrides the initiating parents' wishes, with no claim against the natural father for child support. Of course, she would have the option of giving the child up for adoption. Contra Note, Developing a Concept of the Modern "Family": A Proposed Uniform Surrogate Parenthood Act, 73 GEO. L.J. $1283,1310-16$ (1985) (arguing for specific performance of all terms of surrogate contract).

62. Such a standard would require that even liquidated damages for contract violations not be levied against a surrogate mother. Although enforceability of liquidated damages provisions would create an incentive for the surrogate mother to honor the contracted wishes of the initiating parents, and by corollary to take fewer risks with the child, the right of privacy and the preserve of motherhood require that the incentive go the other way. It is appropriate for initiating parents to bear the burden of diligent searching for a trustworthy surrogate mother, rather than to have the surrogate mother bear the burden of privacy invasions and threat of sanction. This incentive structure raises the cost and risk incurred by initiating parents, therefore perhaps deterring their engagement in such a collaborative process. However, the net result is that only carefully prepared surrogate arrangements with reduced potential for conflict take place.

63. See generally Waltz \& Thigpen, Genetic Screening and Counseling: The Legal and Ethical Issues, 68 Nw. U.L. REv. 696, 702-29 (1973). But see Blank, Human Sterilization: Emerging Technologies and Reemerging Social Issues, SCI. Tech. \& Hum. Values, Summer 1984, at 8, 15-16 (warning against potential use of reversible sterilization for compulsory eugenics).

64. A surrogate mother should not be evaluated as a professional, and the existence of a contract should not mislead a court into thinking otherwise. Motherhood is not the kind of experience that is repeated for the purpose of gaining expertise. For traditional mothers and surrogate mothers alike, the ability and knowledge to control gestation is inevitably limited. 
child would be perfect. Accordingly, they cannot assume a right to a perfect child by using a surrogate mother. Because a surrogate mother has no duty to produce a perfect child, she should not be held liable for a defective child. ${ }^{65}$ Biological unknowns, problems of proof, human weakness, and indeterminate motivation on the part of the surrogate mother to produce a healthy child create residual risks, which may not clearly fall on any particular actor in the process. By initiating the process and involving third parties, the initiating parents must be prepared to carry those residual risks, since both their rights and obligations are transcendent throughout the process. ${ }^{68}$

\section{Stage Four: The Ghild Raising Stage-Balancing Rights IN FAVOR OF PSYchology}

The circuitous route by which parental rights are vested in the ultimate parents is a by-product of misapplied family law. Assuming that the majority of surrogate arrangements are completed without conflict, parental rights should vest in the initiating parents automatically upon birth of the child. Such an immediate transfer would expediently place rights and obligations on the parties who initially intended to assume them. ${ }^{67}$ In the most equitable legal regime, a strong presumption of appropriation should be the standard through which full parental rights vest in the initiating parents. ${ }^{68}$ In rare instances, the surrogate mother could rebut the pre-

65. The issue to be resolved in surrogate mothering is distinctly not that of reducing defects in children, but of reducing overall injuries to the parties involved. Surrogate mothers are sought by precisely those parents for whom the likelihood of defective offspring is great. Courts tend to premise that a child born with a defect is a net gain, as shown by courts' reluctance to entertain suits for wrongful life. See, e.g., Trotzig, The Defective Child and the Actions for Wrongful Life and Wrongful Birth, 14 FAM. L.Q. 15, 30-32 (1980). The complications of trying to trace damages into the home of the surrogate mother make damage claims for defective children especially inappropriate.

66. In essence, the initiating parents must contend with a situation of "reverse" product liability. They, as consumers, must bear the major risk, rather than the surrogate mother, as producer. Product liability has arisen partly because producers have substantial control over the quality of their product, and partly because of deep pocket concerns. See, e.g., James, General Products-Should Manufacturers Be Liable Without Negligence?, 24 TENN. L. REV. 923 (1957). Neither is applicable to surrogate mothers. Instead, the zone of protection for motherhood prohibits liability for "faulty" births. After tasks are meted out to third parties, residual risks should fall on the initiating parents.

67. A legal system that immediately transfers rights to the initiating parents would alleviate the need for excessive state intervention. Despite the state's role of parens patriae, it is difficult to justify more than minimal state intervention if the parents want the child, the surrogate mother has offered her informed and willing consent, and the amount of compensation is reasonable. Rushevsky, supra note 20 , at 113 n.45. Accordingly, the requirement of undergoing full adoption investigations in both Baby Girl, 9 Fam. L. Rep. (BNA) 2348, and RKS, 10 Fam. L. Rep. (BNA) 1383, is excessive. See infra note 79 (discussing presumption of fitness).

68. Without a strong presumption, the surrogate mother could be plagued throughout the pregnancy with doubts of whether or not she should relinquish the child. If she clearly understands from the beginning that the surrogate contract entails a legal commitment, she will be less likely to waiver during her pregnancy and will be spared much of the psychological pain of ambivalence which greater legal discretion would entail. 
sumption, ${ }^{69}$ but she would be seeking to regain the rights to the child, rather than seeking to retain them. ${ }^{70}$

A presumption of appropriation for the initiating parents would conflict directly with the traditional presumption of biology for maternal rights, as well as the presumption of legitimacy still found in some states. ${ }^{71}$ However, surrogate parenting arrangements differ significantly from the family that courts have traditionally protected. The fact that the initiating parents mentally conceived of the child and afforded it existence prior to the surrogate mother's involvement must be acknowledged along with the fact that the surrogate mother entered the arrangement as a third party, willing to assist the initial parents, and that her husband, if she has one, consented to the arrangement with the understanding that the child would not be his-either biologically, psychologically, or legally. Balancing risks and benefits, the initiating parents should be responsible for a child that no one wants, and they should be entitled to a child that everyone wants. ${ }^{72}$

69. A petition by the surrogate mother to keep the child would confront the court with its most difficult situation in surrogate arrangements, but the presumption should not be easily rebutted. However, in a case where complications from a surrogate pregnancy result in subsequent sterility, the surrogate mother would have a heightened claim to the child. Likewise, in a case of extreme duress where inadequate counseling results in the surrogate mother's lack of understanding in contracting for her role, equity may require that she keep the child. In such a case, the initiating parents may also have a claim against the lawyer. See supra note 57.

An alternative approach, more favorable to the surrogate mother, would be to give her an option during stage three to keep the child. However, unless the surrogate mother formally petitions during stage three to retain the rights to the child, the automatic transfer of parental rights would occur at birth. This Note does not advocate this approach, but offers it in recognition of criticisms that weigh the interests of the surrogate mother more heavily.

Carol Gilligan argues that legal analysis should be care-based as well as rights-based. See The 1984 James McCormick Mitchell Lecture: Feminist Discourse, Moral Values, and the Law-A Conversation, 34 Buffalo L. REv. 11, 36-50, 58-64 (1985). Such analysis requires positive valuation of relationships between people. Specifically, the enforceability of contractual obligations in surrogate motherhood would be colored by the formation of attachments. For Gilligan, the inevitable attachment developed between surrogate mother and child should not be overcome by a prior contract to relinquish the child. Discussion with Carol Gilligan, Harvard University Associate Professor of Education, at Yale Law School (Feb. 18, 1986). However, the surrogate contract also brings into being an attachment of the initiating parents to the child. Attachment does not arise only from physical experience or possession, and denying the initiating parents the child would infringe upon a care-based relationship. What makes surrogate motherhood so difficult is the potential for incompatible care-based claims. In Gilligan's own words, "it is a dilemma of connection, not a dilemma of contest." Presentation by Carol Gilligan, Yale Law School (Feb. 17, 1986) (referring to abortion). This Note strives to preserve a care focus within the context of a rights analysis.

70. A Canadian study commission recommended an even more absolute position: "We have been persuaded that, on balance, the legislation should provide for immediate surrender of the child. Hence, where a surrogate mother refuses to transfer custody, she could be compelled to do so by court order." Ontario Law Reform Commission, Report on Human artificial Reproduction AND Related Matters iv(a) (1985) [hereinafter OnTaRio RePORT].

71. See, e.g., Ark. H. 865, Reproductive Law Rep., supra note 6, at R71 (proposed bill for surrogate motherhood codifying presumption of legitimacy).

72. The framework presented by Calabresi and Melamed for the determination of rights and obligations provides a basis for the creation of entitlements in initiating parents. Calabresi \& Melamed, Property Rules, Liability Rules, and Inalienability: One View of the Cathedral, 85 Harv. L. REv. 1089 (1972). The legal relationships in surrogate arrangements should be protected by a system 
While the suggested legal guidelines strive to accommodate the interests of the two biological parents as well as the interests of their respective spouses, they also provide for the well-being of the child. The interests of the child are served by a system that places the child in parental hands as unambiguously as possible. ${ }^{73}$ Any conflicting claims to the child should be resolved as smoothly and immediately as possible. Once the child has changed hands, the arrangement should be final. ${ }^{74}$ Courts in surrogate cases have given little consideration to the child. Most often, the child had already been relinquished by one set of parents by the time the court rendered a final decision. ${ }^{75}$ While a brief notation may have mentioned the

of property rules, in which the legal entitlement may only be forfeited with the consent of the holder. By incorporating property rules into surrogate mother contracts, a relatively straightforward and consistent system of rights can be established. "Property" is used as a term of art coined by Calabresi and Melamed, rather than in the traditional sense of the market right to buy and sell. Courts vehemently reject analysis of children as property. See Doe v. Kelley, 6 Fam. L. Rep. (BNA) 3011,3013 (Mich. Cir. Ct. 1980); Op. Kan. Att'y Gen. No. 82-150 (July 2, 1982).)

Liability rules, which involve the assessment of a socially determined value for an entitlement, are unworkable because of the difficulty of ascertaining and calculating damages. See Note, Surrogate Mothers: The Legal Issues, 7 AM. J.L. \& MED. 323, 335-36 (1981). A court should not consider compensation for initiating parents except in a case of extreme negligence where there is a directly measurable and allocable cause for the child's defect.

73. Failure to provide clear legal guidelines could result in more cases like the tragic saga of Malahoff and Stiver. See Andrews, The Stork Market: The Law of the New Reproduction Technologies, 70 A.B.A. J. 50, 56 (1984) (rejection by all parties of microcephalic child); see also Fagen, They're Stealing My Baby Girl, N.Y. Post, Aug. 22, 1986, at 4, col. 1 (custody battle over surrogate baby).

74. A statutory proposal in South Carolina, S.C. H. 2098, would allow the adoption decree obtained by the wife of the natural father to be challenged up to a year later. Reproductive Law Rep., supra note 6, at R100, R106. Such a length of time would be harsh for the infertile wife and potentially damaging for the child. See J. Goldstein, A. Freud \& A. Solnit, Beyond THE Best INTERESTS OF THE CHILD 17-21 (1973). Children are particularly vulnerable to trauma from severed relationships during their first two years. See Note, Adoption-Psychological v. Biological Parenthood in Determining the Best Interests of the Child, 3 SETON HALL L. Rev. 130, 137-38 (1971). Damage to the child was recognized by a Canadian commission:

[I]mmediate surrender would serve to prevent bonding with the surrogate mother and to facili-

tate bonding with the person-the social mother-who, in the vast majority of cases, would be

the ultimate recipient of the child and who, therefore would be the primary influence in its life

during the neonatal period and infancy.

ONTARIO REPORT, supra note 70. Out of similar concern for protecting both mother and child, adoption decrees are very rarely annulled. See C. Foote, R. Levy \& F. SANDER, CASES AND Materials on Family Law 425 (1985).

75. At the time of the hearing, the child in In re Baby Girl, 9 Fam. L. Rep. (BNA) 2348 (Ky. Cir. Ct. 1983), was in the possession of the initiating parents as originally contracted, but this fact was relevant to the court only to the extent that the transfer had taken place without official permission. By the time of the final judgment in Syrkowski v. Appleyard, 122 Mich. App. 506, 333 N.W.2d 90 (1983), the daughter was almost four years old and had been living with the initiating parents. To have refused them parental rights would have disrupted the child's stable home environment, but again, the child's welfare was not an issue for the court. Indeed, in refusing to allow the natural father to become the legal father, the Michigan Court of Appeals rather lamely footnoted: "On reaching our decision our concern has included the ultimate effect upon the child Theresa. The Supreme Court was aware of the problem of identifying the legal parents of the child in [a similar case, Kelley]; the Court, however, denied leave to appeal." Syrkowski, 333 N.W.2d at 94 n.3. Given that the purpose of a surrogate arrangement is the child itself, the failure of courts to discuss the child is paradoxical. 
whereabouts of the child, final decisions of surrogate cases have included neither an assessment of the best interest of the child, ${ }^{78}$ the prevalent standard in family law cases concerning children, ${ }^{77}$ nor even the assurance of an adequate interest of the child. The state has an interest in a fit gestational mother and fit social parents for all children; however, in both surrogate parenting and natural procreation, there are limits to state intrusion.

To accompany the presumption of appropriation, courts in surrogate cases should use a standard of adequate care for the child. ${ }^{78}$ Especially in situations where both the initiating parents and the surrogate mother want the child, case-by-case determinations of which set of parents might provide the best home environment would be unnecessarily intrusive and arbitrary. ${ }^{79}$ In surrogate parenting cases, the initiating parents should be the designated legal parents with sustained rights to the child. ${ }^{80}$ Indeed, in most cases of procreative collaboration, the parties will agree-and the legal presumptions proposed here will accurately reflect-that the initiating parents should raise the child as originally planned.

\section{ConClusion}

Questions posed by reproductive technologies challenge the most basic tenets of family law. The bifurcated role of women in surrogate arrangements is prompting renewed assessment of the meaning of motherhood and the designation of maternal rights. As intentions to procreate are being realized by assisted forms of reproduction, heightened tensions between biologically endowed rights and psychologically claimed rights must be resolved in the face of increasingly complex reproductive arrangements.

76. But of. Re C, 1985 Fam. 846 (England) (foremost concern is best interest of child). This case was decided before U.K. legislation criminalized surrogate activity, see supra note 8 .

77. See, e.g., Ex parte Devine, 398 So. 2d 686 (Ala. 1981) (tracing historical development of best interest of child standard).

78. The standard is intentionally not "best interest of the child." See infra note 81. Contra Note, Surrogate Parenthood-An Analysis of the Problems and a Solution: Representation for the Child, 12 WM. Mrtchell. L. Rev. 143, 173-81 (1986).

79. From the state's perspective, both sets of parents may be presumed equally fit, or at least equally not unfit, to have custody of the child. Under the presumption of biology, courts presume the biological mother is fit to raise the child. A court similarly can presume that, if initiating parents contract with a surrogate mother for a child, they desire it and intend to care for it well. With a presumption of fitness and a claim of natural parentage on both sides, other factors, such as psychological factors, must tip the balance. See infra note 81 .

80. Rights should remain vested in the designated parents, unless the parents are affirmatively shown to be unfit. See, e.g., In re J.P., 648 P.2d 1364 (Utah 1982) (involuntary termination of parental rights without finding of unfitness is unconstitutional). The state or the surrogate mother should have standing to make a claim of unfitness. The only other time initiating parents would be divested of their rights to the child would be in the rare case where extreme mental duress of the surrogate mother outweighs the emphasis given to mental conception and intention of the initiating parents. See supra note 69. 
The perfunctory reliance on contracts, embodying expectations of service, underscores the need to preserve human integrity within the procreative process. The tensions are especially acute because they challenge wellestablished and far-reaching legal doctrines. As such, they require solutions which come from a widely applicable new perspective. ${ }^{81}$

A carefully designed and consistently applied legal framework can safeguard the interests of all parties involved, from the initiating parents to the collaborating parties to the child. The novelty of new reproductive technologies counsels caution, but given a suitable legal system, the benefits of such procreative alternatives can be realized.

81. An important benefit of the analytic framework presented in this Note is its applicability to other reproductive technologies, such as artificial insemination, embryo transfer, and in vitro fertilization. These other reproductive methods involve the same stages and entail the same divisions between stages as shown in the diagram of surrogate motherhood. See supra note 24 and accompanying diagram. Although different processes vary regarding the specific parties active at each stage, use of the matrix to shift rights according to the stages is invariably helpful.

While the matrix helps identify the rights of procreating parties at various stages, a general scheme for prioritizing rights would be useful as a further refinement for resolving cases of conflict. The inclusion of psychological aspects revises the process by which courts should determine placement of a child produced by artificial reproduction. Determinations should be made through a tiered analysis of three questions: (1) Who are the biological parents? (2) Who are the psychological parents? and (3) Are the interests of the child violated? If answers to the first two questions differ, the biological identity of a parent should not presumptively prevail over the psychological aspects of the parent-child relationships. This Note has argued that priority should be given to the mentally conceiving parents. After the court has determined which parents have legal rights, the third question serves only to ensure the adequate interest of the child. 